\title{
EuroSCORE II and the importance of a local model, InsCor
}

\author{
L Lisboa,, O Mejia, L Moreira, L Dallan, PMA Pomerantzeff, L Dallan, M Massoti, D Vianna, F Jatene \\ From 23rd World Congress of the World Society of Cardio-Thoracic Surgeons \\ Split, Croatia. 12-15 September 2013
}

\section{Background}

The most widely used model for predicting mortality in cardiac surgery was recently remodeled, but the doubts regarding its methodology and development have been reported.

The aim of this study was to evaluate the performance of the EuroSCORE II to predict mortality in patients undergoing coronary artery bypass grafts or valve surgery at our institution.

\section{Methods}

One thousand consecutive patients operated on coronary artery bypass grafts or valve surgery, between October 2008 and July 2009, were analyzed. The outcome of interest was in-hospital mortality. Calibration was performed by correlation between observed and expected mortality by Hosmer Lemeshow. Discrimination was calculated by the area under the ROC curve. The performance of the EuroSCORE II was compared with the EuroSCORE and InsCor (local model).

\section{Results}

In calibration, the Hosmer Lemeshow test was inappropriate for the EuroSCORE II $(\mathrm{P}=0.0003)$ and good for the EuroSCORE $(\mathrm{P}=0.593)$ and InsCor $(\mathrm{P}=0.184)$. However, the discrimination, the area under the ROC curve for EuroSCORE II was 0.81 [95\% CI (.76 to .85), $\mathrm{P}<0.001$ ], for the EuroSCORE was 0.81 [95\% CI $(0.77$ to 0.86$), \mathrm{P}<0.001]$ and for InsCor was 0.79 [95\% CI (0.74-0.83), P 0.001] showing up properly for all.

\footnotetext{
* Correspondence: luiz.lisboa@incor.usp.br

Cardiovascular Surgery Department, Heart Institute (InCor), Hospital das

Clínicas da Faculdade de Medicina da Universidade de São Paulo, São Paulo,
} Brazil

(c) 2013 Lisboa et al; licensee BioMed Central Ltd. This is an Open Access article distributed under the terms of the Creative Commons
Cite this article as: Lisboa et al:: EurOSCORE II and the importance of a local model, InsCor. Journal of Cardiothoracic Surgery 2013 8(Suppl 1): 0115.
Submit your next manuscript to BioMed Central and take full advantage of:

- Convenient online submission

- Thorough peer review

- No space constraints or color figure charges

- Immediate publication on acceptance

- Inclusion in PubMed, CAS, Scopus and Google Scholar

- Research which is freely available for redistribution Submit your manuscript at
www.biomedcentral.com/submit C BioMed Central 